\title{
ON THE SCALE OF HETEROGENEITIES IN CLINOPYROXENES OF SPINEL LHERZOLITE XENOLITHS FROM OAHU, HAWAII: IMPLICATIONS FOR NON-MODAL ADVECTION-DIFFUSION CONTROLLED TRACE ELEMENT ENRICHMENT.
}

\author{
G. Sen
}

Department of Geology, Florida International University, Miami, Florida 33199.

Ion and electron microprobe investigation of clinopyroxenes of Hawaiian spinel lherzolite xenoliths was undertaken to examine the scale of major, minor, and trace element variabilities in the Hawaiian upper mantle. A total of about 50 xenoliths were examined, and these come from Kaau, Pali, Kalihi and Salt Lake vents of the post-erosional Honolulu Volcanics (Fig. 1). Kalihi, Kaau and Pali vents occur close to the caldera area of the Koolau shield volcano, and Salt Lake is situated on the apron of the volcano. Thus, the premise of this study was also to document 3-D variations in the spinel lherzolitic lithosphere on a $\mathrm{km}$-scale beneath an extinct hot spot generated volcano that had also suffered post-erosional magmatism. Whereas opxs are LREE-depleted in all xenoliths, cpxs show a large range: $[\mathrm{Ce} / \mathrm{Sm}] \mathrm{c} . \mathrm{n} .=0.2-2.7$ (Fig. 2). Salt Lake cpxs mostly exhibit LREEenriched to convex upward REE patterns and only one xenolith shows slightly depleted pattern (Fig. 2). Kaau and Pali xenoliths vary from depleted to enriched types. Transitional "Spoon"-shaped (concave upwards between $\mathrm{La}$ and Eu) patterns also occur in all the xenoliths close to the Koolau caldera, but are notably absent in the Salt Lake suite. In individual xenoliths strong intergrain and intragrain REE variation exists. A cpx grain with a spoon-shaped pattern and lower absolute REE contents occurs in the same rock containing another grain with strongly LREE-enriched pattern. Cores are commonly LREE-depleted or spoon-shaped whereas the rims are strongly LREE-enriched or spoon-shaped with higher REE abundance. In composite xenoliths from Salt Lake, cpxs in the pyroxenite (vein) and lherzolite (wall) both have convex-upward REE pattern, and the absolute abundances increase in the wall rock cpx as the vein is approached. It is clear that the starting (protolith) cpx was strongly depleted in LREE (as would be expected of a N-MORB depleted residue. Later non-modal enrichment was caused by fluids related to two periods of magmatic activity - Koolau (tholeiitic) and Honolulu (post-erosional alkalic). The nature of the variations (collectively \& individual cpxs) suggests that selective and differential enrichment of LREEs (but no enrichment Eu-to-Yb) occurred, and it is proposed that the process was an advection-diffusion controlled mechanism. Overall, origin of these heterogeneities is attributed to a combination the following processes: First, fusion and heterogeneous extraction of northern Pacific MORBs depleted the lithosphere. Second, internal deformation (matrix deformation during melt extraction) and metamorphic segregation.processes resulted in the development of porphyroclastic texture and mineral foliation. Third, migrating fluid leaving the asthenosphere cracked and reacted with the lithosphere. Fourth, heating of the lithosphere largely by transient Hawaiian magmas while moving over the hot spot caused the lithosphere to thin, resulting in the conversion of the lower garnet lherzolite layer into a spinel+pyroxene cluster bearing lherzolite (LREE-depleted) of the type found in Pali. Passing Koolau magmas may have further depleted the spinel lherzolite lithosphere in incompatible elements while enriching it in Fe. Finally, significant coarsening of grain size, veining, stoping, Fe, LREE, and Na-enrichment and hydrous mineral precipitation along cracks within the lithosphere occurred during interaction of the lithosphere with parental magmas of the post-shield Honolulu magmas derived from the asthenosphere. 


\section{Summary Diagram}

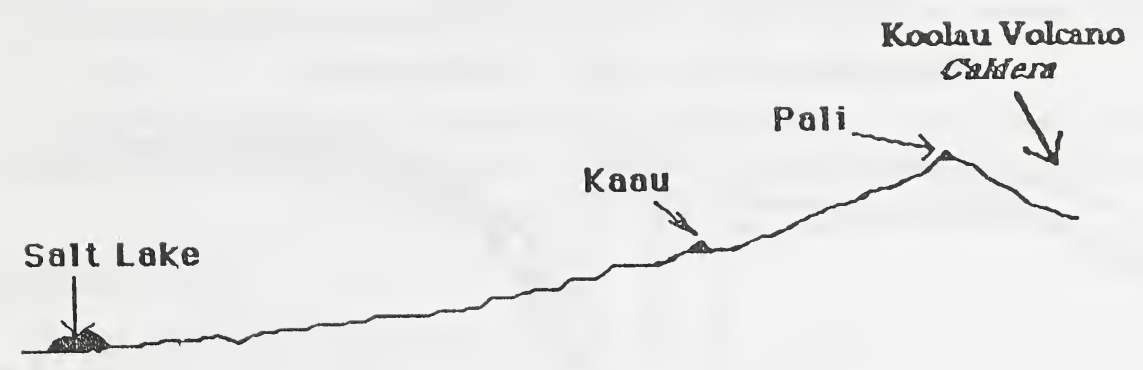

Sp. Lherz

Gt. xenoliths
no dunite*

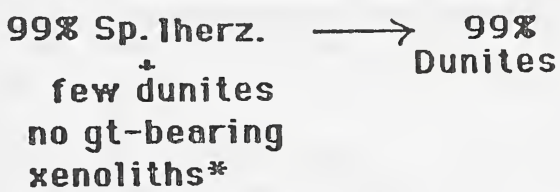

ic.umulotes

in

shollaw megmo

chambers)

Spinel Iherzolite Clinopyrozene Characteristics

\section{Salt Iake}

$\mathrm{Na}, \mathrm{Cr}$ content higher

than in other vents; \&

these values are not co-

rrelated with [Fo] lol

\section{Kaxpl}

$\mathrm{Na}, \mathrm{Cr}$ contents lower:

\& $\mathrm{Na}$ increases with increasing [Fo]
Ulupan/Kalihi

Similar $\mathrm{Na}, \mathrm{Cr}$ as in Koou \& Pali

Fig. 1 Distribution of xenoliths in Honolulu Volcanics

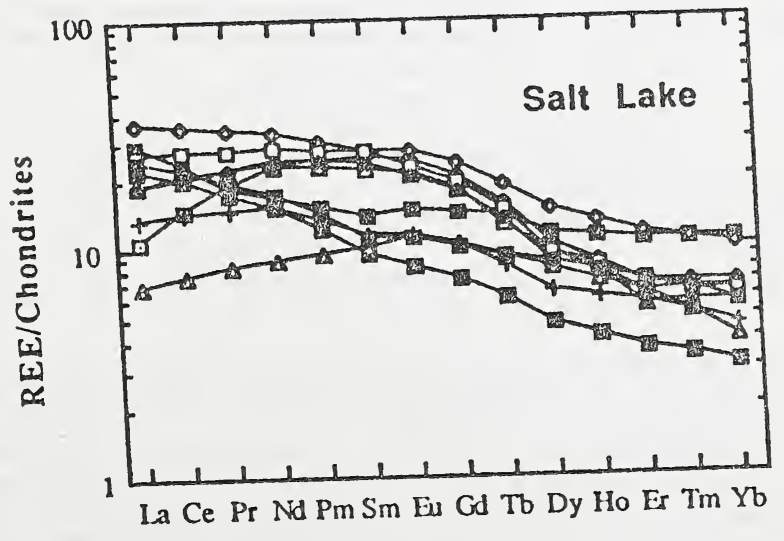

Fig. 2 REE/Chondrite plots for cpxs in spine1 1herzolites from Oahu.

Elements analyzed are: La, Ce, Nd, Sm, Eu, Dy, Er, Yb. Others are interpolated. 

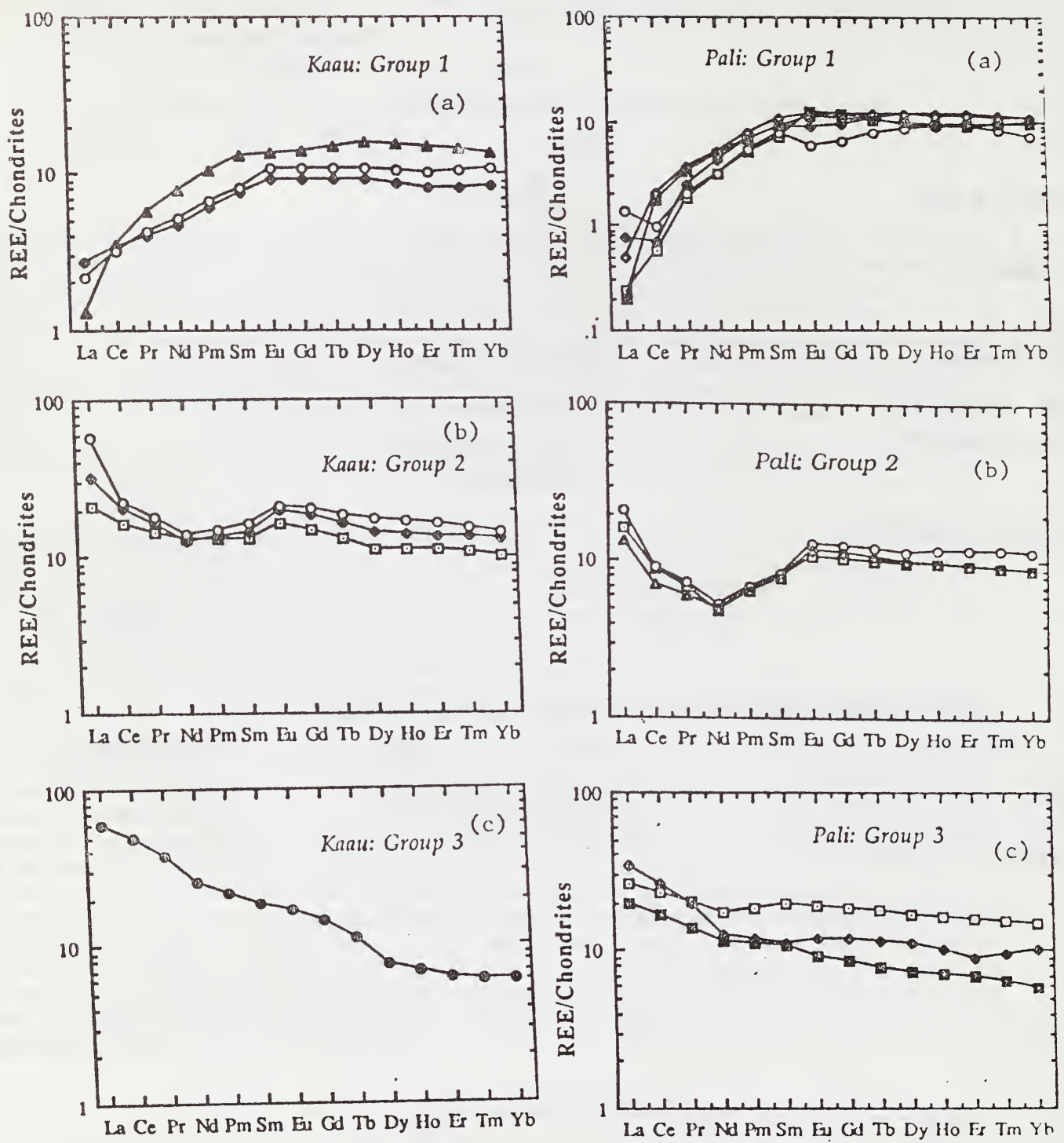

Fig.2 .... Continued. 